\title{
ASIAN PUBLIC INTELLECTUALS' ROLES IN COMBATTING TRAFFICKING IN ASEAN COUNTRIES
}

\author{
Rina Shahriyani Shahrullah**
}

Law and Public Policy Department

Faculty of Law Universitas Internasional, Batam

Jalan Gajah Mada, Baloi - Sei Ladi, Batam 29442

\section{Abstract}

The ASEAN Economic Community which facilitates free movement of people among ASEAN countries may cause a more progressive migration. One of the unintended consequences of migration is human trafficking. This paper suggests that there should be a collaborative measure taken by public intellectuals of ASEAN countries to combat human trafficking. Public intellectuals from receiving and sending countries in ASEAN should share their information, knowledge, roles, responsibilities, resources, and services. This paper emphasizes that Asian public intellectuals as the member community in curbing human trafficking in the ASEAN region should involve government agencies, NGOs and communities.

Keywords: human trafficking, migration, ASEAN.

\section{Intisari}

Masyarakat Ekonomi ASEAN yang menfasilitasi kebebasan penduduk negara anggota ASEAN untuk berpindah dapat menyebabkan terjadinya suatu migrasi besar-besaran. Salah satu konsekwensi yang tidak dikehendaki dari migrasi adalah perdagangan orang. Makalah ini menyarankan perlunya suatu langkah kerjasama yang dilakukan oleh intelektual publik di negara ASEAN untuk memerangi perdagangan orang. Intelektual publik dari negara penerima dan pengirim di ASEAN perlu untuk membagi informasi, pengetahuan, peranan, tanggung jawab, sumber daya, dan pelayanan mereka. Makalah ini menekankan bahwa intelektual publik Asia perlu melibatkan pemerintah, LSM and warga masyarakat.

Kata Kunci: perdagangan orang, migrasi, ASEAN.

\section{Pokok Muatan}

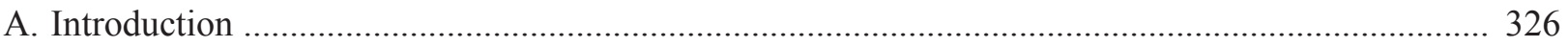

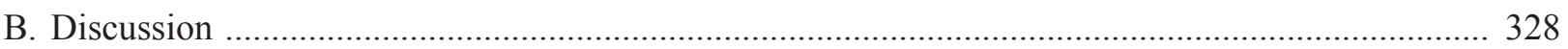

1. Linkage between Migration and Human Trafficking in the ASEAN Region ............................. 328

2. The Approaches of ASEAN and Its Member States to Human Trafficking ................................ 329

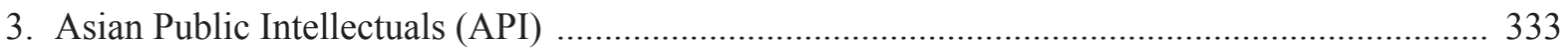

4. Transforming Law in Book into Law in Action by Asian Public Intellectuals ............................ 334

5. Roles of Asian Public Intellectuals to Combat Human Trafficking ............................................. 335

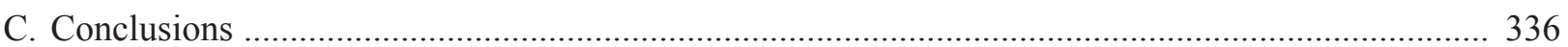

Some parts of the paper were presented in the APSA International Conference from 15 - 16 February 2014 in Chiang Mai, Thailand under the generous funds of the Asian Public Intellectuals (API) Program, the Nippon Foundation, Japan.

** Correspondence address: rina@uib.ac.id 


\section{A. Introduction}

At the $12^{\text {th }}$ ASEAN Summit in January 2007 in Cebu, Philippines, the ASEAN Leaders are committed to accelerate the establishment of an ASEAN Economic Community (AEC) by 2015 as envisioned in the ASEAN Vision 2020. ${ }^{1}$ The ASEAN Vision 2020 clearly stipulates:

We envision our rich human and natural resources contributing to our development and shared prosperity. [...] We commit ourselves to moving towards closer cohesion and economic integration, narrowing the gap in the level of development among Member Countries, ensuring that the multilateral trading system remains fair and open, and achieving global competitiveness. [...] We will create a stable, prosperous, and highly competitive ASEAN Economic Region in which there is a free flow of goods, services and investments, a freer flow of capital, equitable economic development and reduced poverty and socioeconomic disparities.

The AEC 2015 will establish ASEAN as a single market and production and transform ASEAN into a region with free movement of goods, services, investment, skilled labours, and freer flow of capital. ${ }^{2}$ The free flow of skilled labours will raise a crucial challenge for ASEAN member states since each member state has different migration policies. To respond this challenge, all ASEAN member states should 'align their governance and management of labour migration with international and regional obligations, guidance, and best practice'. ${ }^{3}$

Diverse economic strengths among ASEAN member states intensify the movement of people to find a better life in other more developed ASEAN countries. The United Nations reported that there were 70.8 million international migrants in Asia. ${ }^{4}$ There are approximately 100,000 migrant workers in Brunei. ${ }^{5}$ The number of Indonesian migrants in Thailand $(1,459)$, Malaysia $(1,397,684)$, the Philippines (5,865), Cambodia (505). ${ }^{6} 22.156$ migrants from Vietnam live in Laos and 17.039 migrants from Myanmar live in Malaysia. ${ }^{7}$ The flow of migrant workers in the ASEAN region in 2015 will increase and it will not limit to skilled labours and talents as stipulated by the ASEAN 2020. Unskilled migrant workers, particularly those who work at domestic spheres will also increase.

In 2007, ASEAN adopted the ASEAN Declaration on the Protection and Promotion of the Rights of Migrant Workers, ${ }^{8}$ which determines the obligations of ASEAN member states to provide migrant workers with adequate access to the legal and judicial system, to facilitate the exercise of consular function by consular or diplomatic authorities of countries of origin when a migrant worker is arrested or committed to prison or custody or detained in any manner, to set up policies and procedures for facilitating recruitment, preparation for deployment overseas and protection of migrant workers as well as repatriation and reintegration to the countries of origin, and other aspects of worker migration, to establish and promote legal practices for regulating recruitment of migrant workers, to adopt mechanisms for eliminating recruitment malpractices. ${ }^{9}$ In short, the ASEAN Declaration on the Protection and Promotion of the Rights of Migrant Workers aims to promote fair treatment towards migrant workers. The Declaration basically

\footnotetext{
ASEAN, “ASEAN Economic Community Blueprint”, http://www.asean.org/archive/5187-10.pdf, accessed on 12 February 2015. Ibid.

UN Women, "Managing Labour Migration in ASEAN: Concerns for Women Migrant Workers", http://www.unwomen.org. Also available on http://asiapacific.unwomen.org, accessed on 12 February 2015.

United Nations, "Trends in International Migrant Stock: The 2013 Revision", http://www.un.org/en/development/desa/population/, accessed on 12 February 2015.

Department of State, the United States of America, "Trafficking In Persons Report June 2013", http://www.state.gov/documents/ organization/210737.pdf, accessed on 12 February 2015.

A complete data regarding migrants in the ASEAN region can be found in the International Organization for Migrants, "IOM", http://www. iom.int/cms/en/sites/iom/home/about-migration/world-migration.html, accessed on 12 February 2015.

Ibid.

Adopted at the 12th ASEAN Summit, 13 January 2007, Cebu, Philippines, ASEAN, "Declaration on the Protection and Promotion of the Rights of Migrant Workers", http://www.aseansec.org/19264.htm, accessed on 12 February 2015.

Decent Work Country Programme (2006-2010), ILO 2007, p. 158
} 
focuses on legal or documented migrant workers, yet to the some extend, the obligations in the Declaration may also cover illegal or undocumented migrant workers. Although the ASEAN Declaration on the Protection and Promotion of the Rights of Migrant Workers imposes a number of obligations on ASEAN member states, many migrant workers in ASEAN countries still face difficulties, discrimination and even inhumane treatments. The condition is even worse for migrant workers who are qualified as victims of human trafficking.

Human trafficking is a type of slavery in the modern age since it deprives people of human rights and freedom. Therefore, the United Nations declares that human trafficking constitutes a serious crime against human rights. The UN Protocol to Prevent, Suppress and Punish Trafficking in Persons, Especially Women and Children which was adopted by the United Nations in 2000 defines that 'trafficking in persons shall mean the recruitment, transportation, transfer, harboring or receipt or persons, by means of the treat or use of force or other forms of coercion, of abduction, of fraud, of deception, of the abuse of power or of a position of vulnerability of the giving or receiving of payments or benefits to achieve the consent of a person having control over another person, for the purpose of exploitation'.

Human trafficking occurs in the ring of migration. In other words, when migration takes on elements of coercion, force, abduction, fraud, deception or exploitation, it becomes 'human trafficking (Trafficking in Persons)'. Human trafficking incidents are rampant and may be more rampant in the ASEAN region due to the implementation of the AEC 2015. This is because when ASEAN moves towards full economic liberalization and consequently it will benefit the ASEAN people, more ASEAN people from less economic level wish to leave their country to seek better life. Some of those people may not be lucky and trapped into trafficking ring. Within the ASEAN region today, 'Cambodian children are trafficked to Vietnam and Thailand to work as street beggars, Indonesian women are trafficked into Malaysian to work as domestic workers, Laotian men are trafficked onto Thai fishing boats, Vietnamese women are trafficked through false marriages into numerous commercial sex industries, Burmese women are trafficked into Thailand to work as domestic workers'. ${ }^{10}$

It is apparent that human trafficking remains a greater challenge in the ASEAN migration cycle. The questions is 'how and who will respond to this challenge'. Asian Public Intellectuals (API) as a program developed by The Nippon Foundation to establish a pool of intellectuals to meet the challenges of $21^{\text {st }}$ century where Asia would face political, economic, and social challenges can play significant roles to combat human trafficking in the ASEAN region since they are committed to working for the betterment of society by applying their professional; knowledge, wisdom, and experience. Asian Public Intellectuals can adopt various strategies and methods to combat human trafficking because they consist of academics, researchers, media professionals, artists, creative writers, NGO activists, social workers, public servants and others from various Asian countries.

This paper will mainly discuss the significance of collaborative actions between public intellectuals in ASEAN countries to combat human trafficking in the region. More specifically, this paper focuses on international human trafficking rather than domestic trafficking in the ASEAN region. The paper suggests that the sharing model between public intellectuals from (sending country) and the destination country (receiving country) in the ASEAN region should be adopted in order to strengthen a comprehensive collaborative measure against human trafficking in the region.

10 International on Social Welfare, "Trafficking and Related Labour Exploitation in the ASEAN Region", http://www.icsw.org/, accessed on 12 February 2015. 


\section{B. Discussion}

1. Linkage between Migration and Human Trafficking in the ASEAN Region

Human movement or migration among ASEAN countries has occurred long before the establishment of ASEAN on 8 August 1967. The establishment of the AEC 2015 will attract more and more ASEAN people to migrate in the region in order to meet labour shortages in several ASEAN countries. The AEC 2015 will facilitate the free movement of people, particularly migrant workers with skills and talents. Yet, it should be noted that the free movement of people echoed in the AEC 2015 is referred to 'legal or documented migration'. Migration of ASEAN people is not always conducted through a legal and appropriate channel. 'Illegal or irregular' migration also occurs in the ASEAN region when people from one ASEAN member country enter another ASEAN country without having received legal authorization. The IOM reported that 'around 30-40 percent of all migration flows in Asia are estimated to take place through irregular channels'. ${ }^{11}$ In the ASEAN region, 'irregular migration constitutes a sensitive policy issue and irregular migrants are vulnerable to human rights abuses, discrimination, marginalisation and exclusion. ${ }^{12}$ Migrant workers, irregular migrants are among the most vulnerable people and they often perform the "three Ds"- dirty, dangerous and difficult work. In Malaysia, for example, Indonesian irregular migrant workers suffer from a number of exploitation. They often suffer severe restrictions on their freedom of movement; psychological and physical abuse, including sexual abuse in the case of female migrants. Pervasive labor rights abuses in the workplace include extremely long hours of work without overtime pay, no rest days, and incomplete and irregular payment of wages.

A number of ASEAN people have also been smuggled to enter another ASEAN country. The
Protocol against the Smuggling of Migrants by Land, Sea and Air, supplementing the United Nations Convention against Transnational Organized Crime (the UN Migrant Smuggling Protocol) defines 'migrant smuggling as: the procurement, in order to obtain, directly or indirectly, a financial or other material benefit, of the illegal entry of a person into a State Party of which the person is not a national or permanent resident.' Based on this definition smuggled migrants refers only to the illegal movement of persons across international borders. It is often questioned whether smuggled migrants are automatically human trafficking victims. Human trafficking is legally different from migrant smuggling since in order to qualify as 'human trafficking', there are key elements must be fulfilled, namely 'the element of action' which consists of recruitment, transportation, transfer, harbouring or receipt of persons; 'the element of means' which covers threat or use of force or other forms of coercion, abduction, fraud, deception, abuse of power or position of vulnerability, giving or receiving payments or benefits to achieve consent of a person having control over another; 'the element of purpose' which includes exploitation (including, at a minimum, the exploitation of the prostitution of others, or other forms of sexual exploitation, forced labour or services, slavery or practices similar to slavery, servitude or the removal of organs). These elements should not be fulfilled entirely to qualify a trafficking if a victim is a child. To qualify a trafficking in children is only necessary to show an 'action' such as recruitment, buying and selling, for the specific 'purpose' of exploitation. ${ }^{13}$

Based on the legal term, human trafficking is different from migrant smuggling, yet the operation of migrant smuggling may lead to human trafficking action if coercion or deception is used to facilitate the victim's agreement and there is a purpose of exploitation involved in migrating the victim

11 International Organization for Migrants (IOM), "IOM", www.iom-seasia.org, accessed on 12 February 2015.

12 International Council on Human Rights Policy, "Irregular Migration, Migrant Smuggling and Human Rights: Towards Coherence", http:// www.ichrp.org, accessed on 12 February 2015.

13 The Protocol to Prevent, Suppress and Punish Trafficking in Persons, Especially Women and Children (the 2000 UN TIP Protocol), Art. 3(c). 
outside his/her country. It can be argued that migrant smuggling does not require an exploitative purpose or the elements of force, deception or fraud since the smuggled migrant has knowledge and a greater control of the situation, i.e. choice of destination, negotiated fee, etc. Today, it is difficult to draw a clear distinction between human trafficking and migrant smuggling. Many trafficking victims were once migrated as smuggled migrants and then they would end up as trafficking victims when they could not pay the whole fee to the smuggler. In this situation the exploitative end-purposes of trafficking could come into play, especially when the smuggler started to exploit the smuggled migrants and placed them in a debt bondage situation. In the beginning, the status of victims was smuggled migrants and eventually their status could turn to be internal trafficking victims when they were exploited by the smuggler. However, it is still debatable whether the purpose of exploitation is sufficient to qualify smuggled migrants as trafficking victims.

Human trafficking is closely connected to migration and it is an unintended consequence of migration. Human trafficking is a serious phenomenon in the ASEAN region. Most of ASEAN countries are the source, transit and destination countries for men, women, and children trafficked internally and internationally, mostly for the purposes of sexual exploitation and forced labor. Human trafficking in the ASEAN region is driven by the pushing and pulling factors. The pushing factors can be divided into economic, socio-cultural and political factors. Economic factors consist of poverty, lack of job opportunities, imbalanced urban-rural development and insufficient income. Socio-cultural factors are comprised of gender bias, consumerization, dysfunctional family, low education and peer pressure. The pulling factors are the demands of skilled and unskilled jobs in the formal and informal sectors, booming recruitment agencies in many ASEAN countries, mushrooming clubs, and peer influences. Common modus operandi for transborder (international) trafficking are fraudulent documentation, tourist arrangements, Overseas Performing Artists (OPAs), escort services, false marriages, training scheme, blind advertisements, contract substitution, Artist Record Book (ARB), and Au Pair System. ${ }^{14}$

Modus operandi of human trafficking in all ASEAN countries is almost similar. Recruiters target the vulnerable groups by giving the potential victims all kinds of nice and false promises. They frequently use fraud, deception, threats, abuses of authority, debt bondage, marriage or relationships, abduction, confinement, or rape. Recruiters usually seek for potential recruits in local communities, aided by headhunters who know the community and its residents well enough. The headhunters help recruiters convince potential recruits or their parents to allow their children to leave. The recruiters often give cash to the parents. To facilitate transit, a recruit's personal documents, such as his or her birth certificate, are faked. Once in transit, the recruits are not allowed to talk to anyone outside the group and to handle their legal or travel papers. When the recruits reached their destination, they are told that their transportation expenses, along with other incurred expenses, would be deducted from their salary. Having huge debts to pay, they have no choice, but to work as ordered by their recruiters. Most of the recruits finally end up as prostitutes or laborers in bondage. ${ }^{15}$

\section{The Approaches of ASEAN and Its Member States to Human Trafficking}

All ASEAN member states provide national legal instruments to curb human trafficking. Cambodia, Indonesia and the Philippines have ratified the 2000 UN TIP Protocol as it is shown by the following table.

\footnotetext{
14 Rina Shahriyani Shahrullah, “A Comprehensive Study on the Philippines' Legal Approaches to Combat Human Trafficking: Suggestions for Indonesia", http://www.api-fellowships.org/body/international_ws_proceedings/year7.pdf, accessed on 12 February 2015. 
Table 1. Anti-Trafficking Legal Instruments

\begin{tabular}{lll}
\hline $\begin{array}{c}\text { Name of } \\
\text { State }\end{array}$ & National Law & $\begin{array}{l}\text { The 2000 UN TIP } \\
\text { Protocol }\end{array}$ \\
\hline Brunei & The Trafficking and Smuggling of Persons Order of 2004 & - \\
\hline Cambodia & $\begin{array}{l}\text { Law on the Suppression of Human trafficking and Sexual } \\
\text { Exploitation of 2007 }\end{array}$ & 2 July 2005 (r) \\
\hline Indonesia & $\begin{array}{l}\text { Law No. 21 of 2007 concerning the Elimination of Trafficking } \\
\text { in Persons }\end{array}$ & 28 September 2009 (r) \\
\hline Laos & The Lao Penal Law of 2005 (Articles 24 and 27) & 26 September 2003 (a) \\
\hline Malaysia & $\begin{array}{l}\text { The Anti-Trafficking in Persons Act of 2007 (Act 670) - as } \\
\text { Amended in 2010 }\end{array}$ & 26 February 2009 (a) \\
\hline Myanmar & The Anti-Trafficking in Persons Law of 2005 & 30 March 2004 (a) \\
\hline Philippines & The Anti-Trafficking Act of 2003 & 28 May 2002 (r) \\
\hline Singapore & $\begin{array}{l}\text { Women's Charter of 1966 (as amended in 1996) and the Penal } \\
\text { Code }\end{array}$ & - \\
\hline Thailand & The Anti-Trafficking in Persons Act of 2008 (BE 2551/2008) & 18 December 2001 (s) \\
\hline Viet Nam & Viet Nam Penal Code of 1999 (Articles 119-120) & - \\
\hline
\end{tabular}

Source: the author's compilation from various sources.

Among ASEAN countries, Laos, Singapore and Viet Nam have not enacted a special law to regulate human trafficking. It is frequently debated whether it is necessary for all ASEAN member states to enact a national anti-trafficking law. It is also often asked if a national anti-trafficking law can guarantee the elimination of human trafficking in each ASEAN member state. These questions are not easy to answer because the progress of each ASEAN member states in combating human trafficking does not merely rely upon whether it has a special national trafficking law or not. ${ }^{16}$ Brunei in 2004 issued the Trafficking and Smuggling of Persons Order, yet based on the TIPs Report 2013 in 2010 and 2011 Brunei is placed on Tier 2 Watch List and in 2012 and 2013 this state is placed on Tier 2 which is similar to its ranking in 2009. ${ }^{17}$
Cambodia has enacted Law on the Suppression of Human Trafficking and Sexual Exploitation in 2007 and ratified the 2000 UN TIP Protocol on 2 July 2005. However, Cambodia is placed on Tier 2 Watch List in 2013 due to the failure of the Cambodian government to demonstrate progress in its anti-trafficking law enforcement efforts. ${ }^{18}$ Indonesia passed its anti-trafficking law under Law No. 21 of 2007 concerning the Elimination of Trafficking in Persons. This state has also ratified the 2000 UN TIP Protocol on 28 September 2009. Based on the TIPs Report 2013, this state is placed on Tier 2 since the enactment of anti-trafficking law in $2007 .{ }^{19}$ Laos does not have a specific antitrafficking law, but Articles 24 and 27 of The Lao Penal Law of 2005 provide provisions relevant to human trafficking. Based on the TIPs report 2013,

16 Tier 1: Countries whose governments fully comply with the TVPA's minimum standards for the elimination of trafficking. Tier 2: Countries whose governments do not fully comply with the TVPA's minimum standards but are making significant efforts to bring themselves into compliance with those standards. Tier 2 Watch List: Countries where governments do not fully comply with the TVPA's minimum standards, but are making significant efforts to bring themselves into compliance with those standards, and;

a) the absolute number of victims of severe forms of trafficking is very significant or is significantly increasing;

b) there is a failure to provide evidence of increasing efforts to combat severe forms of trafficking in persons from the previous year, including increased investigations, prosecution, and convictions of trafficking crimes, increased assistance to victims, and a decreasing evidence of complicity in severe forms of trafficking by government officials; or

c) the determination that a country is making significant efforts to bring itself into compliance with minimum standards was based on commitments by the country to take additional steps over the next year.

Tier 3: Countries whose governments do not fully comply with the TVPA's minimum standards and are not making significant efforts to do so. Department of State, the United States of America, Op.cit., pp. 44-45.

Ibid., p. 106.

Ibid., p. 117

Ibid., p. 199 
Laos is placed on Tier 2 from 2011 to $2013 .^{20}$ In 2007 Malaysia enacted the Anti-Trafficking in Persons Act of 2007 and it was amended in 2010, yet Malaysia remains on the Tier 2 Watch List. ${ }^{22}$ The progress of this state in combatting human trafficking used to drop to Tier 3 in 2009. Myanmar (Burma) enacted its Anti-Trafficking in Persons Law in 2005, yet since 2005 until 2011 Myanmar was placed on Tier 3. This position of this state from 2012 to 2013 is on Tier 2 Watch List. ${ }^{22}$ The Philippines enacted its Anti-Trafficking Act in 2003 and ratified the 2000 UN TIP Protocol on 28 May 2002. From 2011 to 2013 the Philippines is placed on Tier 2 and this state used to be placed on Tier 2 Watch List in 2009 and 2010. ${ }^{23}$ Singapore has not enacted an anti-trafficking law or ratified the 2000 UN TIP Protocol. A number of provisions relevant to human trafficking is provided by the Women's Charter of 1966 (as amended in 1996) and the Penal Code. Similar to the Philippines, from 2011 to 2013 Singapore is placed on Tier 2 and used to be placed on Tier 2 Watch List in $2010 .{ }^{24}$ Thailand enacted the Anti-Trafficking in Persons Act in 2008, yet since 2010 to 2013 this state is placed on Tier 2 Watch List. ${ }^{25}$ It is interesting that prior to the enactment of its anti-trafficking act, Thailand from 2006 to 2008 was placed on Tier 2. Viet Nam does not enact an anti-trafficking law, yet the Viet Nam Penal Code of 1999 provides relevant provisions governing human trafficking under Articles 119 - 12. This state does not ratify the 2000 UN TIP Protocol, but it is placed on Tier 2 from 2012 to $2013 .{ }^{26}$

The ranking of most ASEAN countries based on the TIP Report 2013 is Tier 2 which means most ASEAN governments do not fully comply with the Trafficking Victims Protection Act's (TVPA) minimum standards but are making significant efforts to bring themselves into compliance with those standards. It is arguable whether the USA TVPA is the appropriate indicator to measure the progress of ASEAN countries in curbing human trafficking in the region. Since there is still no perfect tool for this purpose, the TVPA minimum standards may be used to examine and measure the efforts of ASEAN countries in combatting human trafficking. Apart from the ranking of each ASEAN member state under the TIPS Report 2013, all ASEAN member states has increased their efforts to combat human trafficking either by improving anti human trafficking mechanisms and systems of prevention, protection, prosecution, rehabilitation and collaboration at bilateral and multilateral level. A multilateral MoU has been signed by ASEAN member states in the greater Mekong region in 2004. Myanmar signed a bilateral MoU with Thailand in 2003. Cambodia signed MoU with Vietnam on bilateral cooperation to eliminate trafficking in Children and Women in 2005. Cambodia has MOUs with Thailand which facilitate the return and repatriation of trafficking victims. ${ }^{27}$

Human trafficking is also a complex issue in the ASEAN region; therefore the responsibilities to combat human trafficking should not only be imposed on the ASEAN member states which are categorized as the country of origin (sending countries). The host countries (receiving countries) in the ASEAN region should also perform serious and concrete actions to combat human trafficking. In other words, a collaborative measure among ASEAN member states are required to combat human trafficking comprehensively. Accordingly at the regional level, all ASEAN member states are committed to preventing trafficking in persons, punishing offenders, and protecting victims of

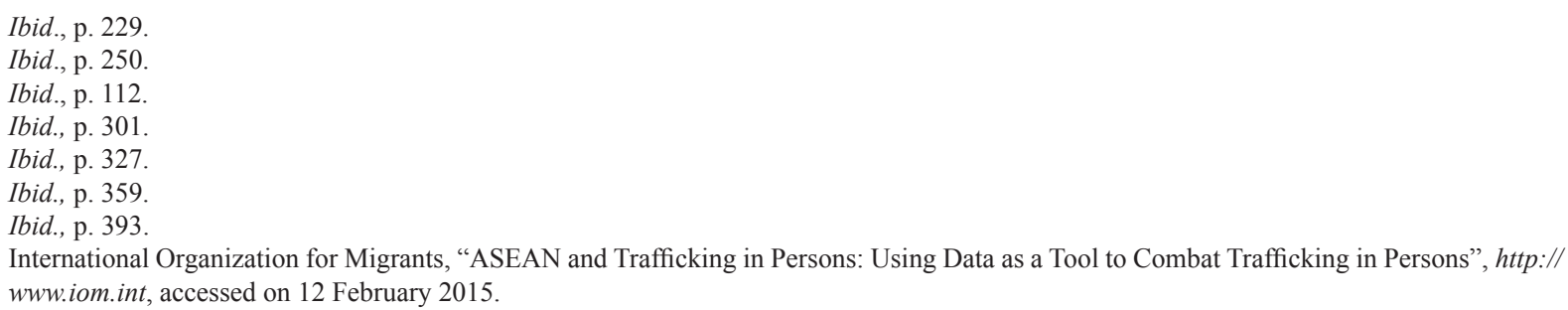


trafficking. These commitments are expressed in the ASEAN Declaration against Trafficking in Persons, especially Women and Children ${ }^{28}$ which was adopted by the Heads of State/Government of ASEAN Member Countries on 29 November 2004 in Vientiane, Lao People's Democratic Republic. The Declaration consists of the following measures:

a. To establish a regional focal network to prevent and combat trafficking in persons, particularly women and children, in the ASEAN region;

b. To adopt measures to protect the integrity of their respective passports, official travel documents, identity and other official travel documents from fraud;

c. To undertake regular exchange of views, information sharing on relevant migratory flows, trends and pattern, strengthening of border controls and monitoring mechanisms, and the enactment of applicable and necessary legislations;

d. To intensify cooperation among our respective immigration and other laws enforcement authorities;

e. To distinguish victims of trafficking in persons from the perpetrators, and identify the countries of origin and nationalities of such victims and thereafter ensure that such victims are treated humanely and provided with such essential medical and other forms of assistance deemed appropriate by the respective receiving/ recipient country, including prompt repatriation to their respective countries of origin;

f. To undertake actions to respect and safeguard the dignity and human rights of genuine victims of trafficking in persons;

g. To undertake coercive actions/ measures against individual and/or syndicate engaged in trafficking in persons and shall offer one another the widest possible assistance to punish such activities; and

h. To take measures to strengthen regional and international cooperation to prevent and combat trafficking in persons.

All ASEAN member states reaffirm their commitment to accomplish the elements of the Declaration and put their maximum efforts to realize these commitments into action. In order to optimize the implementation of the ASEAN Declaration against Trafficking in Persons, especially Women and Children, in 2006 the Inter-agency Ad-Hoc Working Group on Trafficking in Persons was created. The main task of the Inter-agency Ad-Hoc Working Group to establish the 2007-2009 Work Plan to Implement the Declaration. The Work Plan primarily focused on developing common standards and strengthening criminal justice responses. On 27 June 2007 the $7^{\text {th }}$ ASEAN Senior Officials Meeting on Transnational Crime (SOMTC) in Vientiane, Lao PDR endorsed the ASEAN Practitioner Guidelines on Effective Criminal Justice Responses to Trafficking in Persons. The overall objective of these Practitioner Guidelines is to assist the criminal justice agencies of ASEAN Member Countries in their goal of securing justice for victims and ending the impunity of traffickers. ${ }^{29}$ The Guidelines consist of two parts namely: Part one covers evidential matters which consists of strengthening of the legal framework, specialization and co-operation, management of the victim as a witness, special measures for child victims, witness protection issues, and trial issues. Part two covers international operational and legal/judicial co-operation which consists of international operational co-operation, international legal/judicial co-operation in general, international legal/judicial co-operation which specifically governs on extradition, international legal/judicial co-operation dealing with mutual legal assistance in criminal matters and networking particularly between specialist investigators, prosecutors and Central Authority legal officers. 
In addition to the Guidelines, the ASEAN's Senior Officials Meeting on Transnational Crime (SOMTC) also endorsed a Handbook on International Legal Cooperation on Trafficking in Persons Cases in 2008. The Handbook can be used by judicial officials, prosecutors and other criminal justice officials who deal with human trafficking cases. The Handbook consists of five chapters and 'it provides basic information on cooperation tools including mutual legal assistance and extradition as well as guidance on how these tools can be used most effectively in the specific context of regional and international cooperation in TIP cases'. ${ }^{30}$

\section{Asian Public Intellectuals (API)}

As Asia moves into the 21 st century, it faces political, economic, and social challenges that transcend national boundaries. To meet these challenges, the region needs a new pool of intellectuals who are willing to be active in the public sphere and can articulate common concerns and propose creative solutions. Recognizing that opportunities for intellectual exchanges are currently limited by institutional, linguistic and cultural parameters, The Nippon Foundation, in cooperation with major academic institutions in Indonesia, Japan, Malaysia, the Philippines, and Thailand, has launched the Asian Public Intellectuals Fellowships Program (API Fellowships Program). ${ }^{31}$
The API Fellowships program was formally launched on 8th July 2000 and funded by the Nippon Foundation, a private non-profit, grant-making organization based in Japan. The Foundation was established in 1962 and has provided worldwide grant support for the betterment of human life, the development of human resources, the enhancement of social transformation, and the promotion of mutual understanding and exchange. ${ }^{32}$ In recent years, API has expanded to the countries of Cambodia, Laos, Myanmar and Vietnam (CLMV). As of now, 338 fellows have finished their fellowship and join API pool of intellectuals. By profession, API consists of academics, researchers, media professionals, artists, creative writers, NGO activists, social workers, public servants and others with moral authority who are committed to working for the betterment of society by applying their professional knowledge, wisdom and experience. ${ }^{33}$

Recipients of an API Fellowship, past and current, and everyone involved in the API Fellowships Program as selection members, program directors, and coordinators are members of API Community which was declared in 2000. The API Community Vision was declared in Bangkok on 23 July 2006. The vision elaborates the letter of API as it is elucidated in the table below:

Table 2. API Community Vision

\begin{tabular}{ll}
\hline A & P \\
\hline We are a community of multi- Our publics are varied in their Beyond research, self-expression, \\
disciplinary intellectuals localities, size, composition and or public recognition, our work \\
committed to issues related to and contexts. They may be rooted in values intellectual engagement \\
affecting Asia. We recognise our a localised community, confined concerned with the public good. \\
diversity as a strength, respect within a nation-state, or transcend We seek to present ways by which \\
the freedom and autonomy of national boundaries. & $\begin{array}{l}\text { local, national, and regional } \\
\text { our work, and desire to work }\end{array}$ \\
with others who share similar & a fair distribution of power. Our \\
commitments. & advocacy demands discernment, \\
& integrity, and commitment. \\
\hline
\end{tabular}

Surin Pitsuwan, "Foreword by the Secretary-General of ASEAN: ASEAN Handbook on International Legal Cooperation in Trafficking in Persons Cases", http://www.aseansec.org, accessed on 12 February 2015.

Asian Public Intellectuals, “Asian Public Intellectuals (API)”, http://www.api-fellowships.org/body/, accessed on 12 February 2015. Ibid.

Asian Public Intellectuals, “Asian Public Intellectuals (API) Newsletter", http://www.api-fellowships.org/body/archives.php\#newsletters, accessed on 12 February 2015. 
We are committed to knowledge They represent various sectors We contend with everyday work beyond traditional insti- and strata of society. We struggles, our ranks strengthened tutionalised boundaries and nevertheless share a concern for by collaboration. Going past the exploring the meaning and place the marginalised, victimised and traditional role of the intellectual of Asia in a global context. In our oppressed. work, we aspire to bring together as critic or thinker, our network includes anyone with a desire to thinking and doing imbued by Using our knowledge, expertise serve the public good. accountability and transparency. and experience, we are committed

to leaving a legacy to future The API network supports diverse We affirm this sense of ourselves generations - a world that is and creative expression that is in engaging with issues of social, peaceful, progressive, and inclusive in its understanding of cultural and political significance. environmentally healthy - and intellectual work and upholds where humans are responsible a rich heritage of leadership, for each other, and co-exist with collaboration and wisdom in respect and dignity. order to promote social security and change in Asia.

We can do this by working with the publics concerned, with those who are concerned with their issues, as well as those who are responsible for creating the situation.

Source: API Community Document.

\section{Transforming Law in Book into Law in Action by Asian Public Intellectuals}

It is obvious that all ASEAN member states have been provided with a complete set of legal instruments, guidelines and handbook on how to implement the ASEAN legal instruments. Yet, a question remains whether human trafficking incidents can be minimized after the issuance of the instruments, guidelines and handbook. The answer to this particular question should be best approached by a legal theory which is developed by Mochtar Kusumaatmadja and Satjipto Rahardjo.

Mochtar Kusumaatmadja developed a theory of law which is called 'teori hukum pembangunan' (Law-Development Theory). This theory is derived from the theory of Roscoe Pound that points out the end of law as follows:

It [the legal order] may well be thought of as a task or as a great series of tasks of social engineering; as an elimination of friction and precluding of waste, so far as possible, in the satisfaction of infinite human desires out of relatively finite store of the material goods of existence' ${ }^{34}$

In the opinion of Roscoe Pound, 'law as a tool of social engineering is more concerned with actual operation of law rather than its abstract content. ${ }^{35}$ Different from Roscoe Pound, Mochtar Kusumaatmadja was in the opinion that law should not be used as 'a tool', but it should be used as 'a means'. According to Mochtar Kusumaatmadja, 'law is a means to maintain order in society'. The role of law is 'to ensure the dynamic changes occur in regular manner'. Law is 'a society's renewal media which means that law should serve as a director for society's actions to support the development'. ${ }^{36}$ Satjipto Rahardjo ${ }^{37}$ established 'teori hukum progressif' (Progressive Legal Theory). This theory emphasizes that 'human interests, namely human welfare and happiness should be the ultimate aim

\footnotetext{
Roscoe Pound, 1946, Interpretation of Legal History, Harvard University Press, Boston, p. 160.

S.N. Dhyani, 1992, Fundamentals of Jurisprudence, Central Law Agency, Allahabad, p. 331.

Mochtar Kusumaatmadja, 1976, Hukum Masyarakat, dan Pembinaan Hukum Nasional, Binacipta, Bandung, p. 4.

Satjipto Rahardjo, "Indonesia Butuhkan Penegakan Hukum Progresif”, Harian Kompas, 15 June 2002.
} 
of law'. The theory regards that law is merely as a process $^{38}$ to achieve the happiness of human; consequently law should be progressive and responsive to meet such objective.

Based on the approaches of Law-Development Theory and Progressive Legal Theory, all abstract contents of ASEAN Declaration, Guidelines, and Handbook should be transformed into concrete actions in order to achieve the goals of ASEAN. All ASEAN governments and their people should play active and concrete roles in combatting human trafficking. Human trafficking should treated as a latent problem of ASEAN people, thus it needs actual and concrete actions from all ASEAN people to tackle the problem comprehensively. It may be argued that the involvement of all ASEAN people to combat human trafficking is impossible since the understanding of all ASEAN people on human trafficking issues is still lacking. This is true that most of ASEAN people are still not aware of human trafficking issues, therefore the first step is to communicate the issues to all member societies in
ASEAN countries. The task of communicating the human trafficking issues can be well conducted by Asian Public Intellectuals, particularly those from ASEAN countries.

\section{Roles of Asian Public Intellectuals to Combat Human Trafficking}

API which consists of academics, researchers, media professionals, artists, creative writers, NGO activists, social workers, public servants and others with moral authority should become frontliners to communicate and combat human trafficking in their own societies. Their commitment to working for the betterment of society by applying their professional knowledge, wisdom and experience can be used as a means to curb international trafficking as well. Asian Public intellectuals can work individually or together with other public intellectuals from the ASEAN region based on their field of work/ interests and competencies. The following table shows concrete actions which can be done by Asian public intellectuals, particularly those from the ASEAN countries.

Table 3. Responses of Asian Public Intellectuals to Combat Human Trafficking

\begin{tabular}{|c|c|}
\hline $\begin{array}{l}\text { Type of Asian Public } \\
\text { Intellectuals }\end{array}$ & Concrete Actions Against Human Trafficking \\
\hline Academics & $\begin{array}{l}\text { - Teaching students and integrating human trafficking in the courses or } \\
\text { curriculum } \\
\text { - Conducting research } \\
\text { - Publishing research findings } \\
\text { - Presenting papers, etc. }\end{array}$ \\
\hline Researchers & $\begin{array}{ll}\text { - } & \text { Conducting research } \\
\text { - } & \text { Publishing research findings, etc. } \\
\end{array}$ \\
\hline Media Professionals & $\begin{array}{ll}\text { - } & \text { Publishing articles on newspapers/magazines including e-publications } \\
\text { - } & \text { Broadcasting talkshows or dialogues on TV, etc. }\end{array}$ \\
\hline Artists & $\begin{array}{l}\text { - Producing artistic works containing messages to combat human trafficking } \\
\text { - Write songs and poems on human trafficking } \\
\text { - Performing musical concert, theater/acts, movies for human trafficking } \\
\text { victims } \\
\text { - } \quad \text { Conducting exhibitions with human trafficking themes, etc. }\end{array}$ \\
\hline Creative Writers & $\begin{array}{l}\text { - Writing scripts, novels, comics including e-books with human trafficking } \\
\text { themes, etc. }\end{array}$ \\
\hline NGO Activists & $\begin{array}{l}\text { - Establishing programs/activities relating human trafficking for communities } \\
\text { - } \quad \text { Assisting and outreaching human trafficking victims, etc. }\end{array}$ \\
\hline
\end{tabular}

38 Satjipto Rahardjo, “Hukum Progresif: Hukum yang Membebaskan”, Jurnal Hukum Progresif, Vol. 1, No. 1, April 2005, p. 16. 


\begin{tabular}{ll}
\hline Social Workers & - Assisting human trafficking victims \\
& - Becoming volunteers including pro bono legal consultations (pro bono \\
& lawyers), etc. \\
\hline Public Servants & - Implementing good governance \\
& - Providing reliable public services and transparent information \\
& - Being honest and fair in performing their tasks, especially for law enforcers, \\
& etc. \\
\hline
\end{tabular}

Source: the author's analysis.

In addition to conduct concrete actions in their own country, it is suggested that Asian public intellectuals also establish a collaborative engagement with other public intellectuals in other ASEAN countries. They should be transparent and open in sharing information, knowledge, roles, responsibilities, resources and services relevant to human trafficking. The sharing model ${ }^{39}$ below can be used by all public intellectuals in ASEAN countries in their efforts to combat human trafficking in the ASEAN region. The implementation of the sharing model is a challenge not only for Asian public intellectuals in the ASEAN region, but it is also a challenge for public intellectuals in the global world.

\section{Figure 1. Asian Public Intellectuals Sharing Model}

\section{Global Challenges}

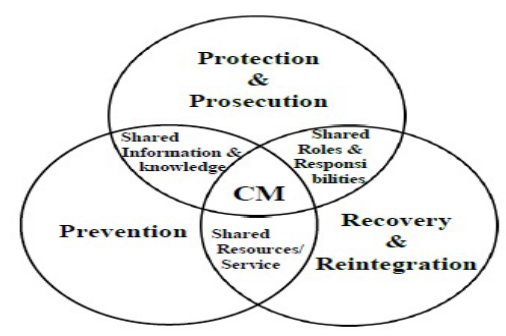

Cooperative Measure $(\mathrm{CM})$ :

Internal Collaboration and International Collaboration

Source: The Authors' Sharing Model, 2010.

\section{Conclusion}

The AEC 2015 will transform ASEAN into a region with free movement of goods, services, investment, skilled labours, and freer flow of capital.
The free flow of skilled labours and talents may be followed by the flow of unskilled labours who wish to find a better life in other ASEAN countries. Up to now, many migrant workers in ASEAN countries still face difficulties, discrimination, and even inhumane treatments. The worst conditions for migrant workers remain unsolved, particularly migrant workers who are qualified as human trafficking victims. When migration takes on elements of coercion, force, abduction, fraud, deception, or exploitation, it becomes 'human trafficking (Trafficking in Persons)'. Human trafficking incidents are rampant and may be more rampant in the ASEAN region due to the implementation of the AEC 2015 because when ASEAN moves towards full economic liberalization, more ASEAN people from less economic level wish to leave their country to seek better life.

Human trafficking is as a latent problem of the ASEAN governments and ASEAN people, thus actual and concrete actions from all ASEAN stakeholders are required to tackle the problem. All ASEAN member states are committed to preventing trafficking in persons, punishing offenders, and protecting victims of trafficking. These commitments are expressed in the ASEAN Declaration against Trafficking in Persons, especially Women and Children.

To realize the commitments, all ASEAN governments and ASEAN people should play active and concrete roles in combatting human trafficking. It becomes imperative to raise awareness on human trafficking to all ASEAN people. All stakeholders should actively participate to deliver this task. Asian

39 The Sharing model was firstly presented by Rina Shahriyani Shahrullah, "Asian Alternatives for a Sustainable World: Trans-border Engagements in Knowledge Formation", Paper, the $7^{\text {th }}$ Asian Public Intellectuals Workshop, Yogyakarta, 22 - 26 November 2008. 
public intellectuals which consist of academics, researchers, media professionals, artists, creative writers, NGO activists, social workers, public servants, and others with moral authority should become front liners to communicate and combat human trafficking in their own societies. Their commitment to working for the betterment of society by applying their professional knowledge, wisdom and experience can be used as a means to curb transborder (international) trafficking as well. Asian Public intellectuals can work individually or together with other public intellectuals from all over the world based on their field of work/interests and competencies.
Since the AEC is approaching, all ASEAN governments and ASEAN people should be ready with all positive and negative impacts of the AEC 2015. Many challenges will be faced by ASEAN in the area of migration when the AEC 2015 is in place. Yet, all challenges in migration including human trafficking issues should be wisely resolved by involving all ASEAN people. People-to-people contact in the ASEAN region should be started from the grassroots, so ASEAN people will consider the problems in migration and human trafficking as their own problems. The active roles of ASEAN people through their concrete actions can provide sustainable solutions for human trafficking.

\section{REFERENCES}

\section{A. Book}

Dhyani, S.N., 1992, Fundamentals of Jurisprudence: The Indian Approach, Central Law Agency, Allahabad.

Kusumaatmadja, Mochtar, 1976, Hukum Masyarakat, dan Pembinaan Hukum Nasional, Binacipta, Bandung.

Pound, Roscoe, 1946, Interpretation of Legal History, Harvard University Press, Boston.

\section{B. Article Journal}

Rahardjo, Satjipto, "Hukum Progresif: Hukum yang Membebaskan", Jurnal Hukum Progresif, Vol. 1, No. 1, 2005.

\section{Paper}

Shahrullah, Rina Shahriyani, "Asian Alternatives for a Sustainable World: Trans-border Engagements in Knowledge Formation", Paper, the $7^{\text {th }}$ Asian Public Intellectuals Workshop, Yogyakarta, Indonesia, 22-26 November 2008 .

\section{Newspaper}

Rahardjo, Satjipto, "Indonesia Butuhkan Penegakan Hukum Progresif", Harian Kompas, 15 June 2002.

\section{E. Article Internet}

Asian Public Intellectuals, "Asian Public Intellectuals (API)", http://www.apifellowships.org/body/, accessed on 12 February 2015.

Asian Public Intellectuals, "Asian Public Intellectuals (API) Newsletter", http:// www.api-fellowships.org/body/archives. php\#newsletters, accessed on 12 February 2015.

ASEAN, "Declaration on the Protection and Promotion of the Rights of Migrant Workers", http://www.aseansec.org/19264. htm, accessed on 12 February 2015.

ASEAN, "ASEAN Economic Community Blueprint", www.asean.org/archive/5187-10. $p d f$, accessed on 12 February 2015.

ASEAN, "ASEAN Handbook on International Legal Cooperation in Trafficking in Persons Cases", http://www.aseansec.org, accessed on 12 February 2015.

Department of State, the United States of America, "Trafficking in Persons Report June 2013", www.state.gov/documents/ organization/210737.pdfi, accessed on 12 February 2015.

International Council on Human Rights Policy, 
"Irregular Migration, Migrant Smuggling and Human Rights: Towards Coherence", htttp:// www.ichrp.org, accessed on 12 February 2015.

International on Social Welfare, "Trafficking and Related Labour Exploitation in the ASEAN Region", http://www.icsw.org/, accessed on 12 February 2015.

International Organization for Migrants (IOM), "IOM", http://www.iom-seasia.org, accessed on 12 February 2015.

, "World Migration", http://www.iom. int/cms/en/sites/iom/home/about-migration/ world-migration.html, accessed on 12 February 2015. , "ASEAN and Trafficking in Persons: Using Data as a Tool to Combat Trafficking in Persons", http://www.iom.int, accessed on 12 February 2015.
United Nations, "Trends in International Migrant Stock: The 2013 Revision", http://www. un.org/en/development/desa/population/, accessed on 12 February 2015.

UN Women, "Managing Labour Migration in ASEAN: Concerns for Women Migrant Workers", http://www.unwomen.org, accessed on 12 February 2015.

Pitsuwan, Surin, "Foreword by the SecretaryGeneral of ASEAN: ASEAN Handbook on International Legal Cooperation in Trafficking in Persons Cases", http://www. aseansec.org, accessed on 12 February 2015. Shahrullah, Rina Shahriyani. "A Comprehensive Study on the Philippines' Legal Approaches to Combat Human Trafficking: Suggestions for Indonesia", http://www.api-fellowships. org/body/international_ws proceedings/ year7.pdf, accessed on 12 February 2015. 